\title{
LE POSSIBILITÀ DEL PENSIERO TRA LIBERTÀ POLITICA, SFERA PUBBLICA E RICERCA DELLA VERITÀ: HANNAH ARENDT E ALASDAIR MACINTYRE A CONFRONTO
}

The possibility of Thought among Political freedom, Public sphere and inquiry to truth: Hanna Arendt and Alasdair Maclntyre in confrontation

Resumo: Proponendo un confronto ragionato, anche se comprensibilmente circoscritto a un numero ridotto di temi, fra la riflessione di MacIntyre e il pensiero di Hannah Arendt, vorrei contribuire alla comprensione di che cosa, nell'opera del pensatore scozzese, si debba oggi tentare di mantenere, se non anche di valorizzare. Per questo mi richiamerò innanzitutto ai motivi per cui Arendt non ha mai accettato che un vero o presunto ritorno a una qualche tradizione filosofica potesse risolvere i tanti problemi nati al seguito dei soggettivismi e dei prospettivismi moderni, riassumibili nella considerazione che la modernità è stata l'occasione con cui la filosofia occidentale ha preso un sostanziale congedo sia dal common sense sia da quell'azione nella sfera pubblica che era essenziale al pensiero greco classico e che pure si trova alla base della concezione europea di una politica ispirata al modello deliberativo.

Parole chivae: Arendt, Maclntyre, Sfera publica, verità, libertà politica

Abstract: I claim a reasoned confrontation, however limited to a reduced number of subjects, between Maclntyre's and Hanna Arendt's thought to contribute to the understanding of what in the Scotish thinker's work should be kept or also valued. In order to do that, I will focus mainly on the reasons why Arendt never accepted that a real or supposed return to any philosophical tradition could solve all the problems brought up by modern subjectivism and perspectivism, summarized in the consideration that modernity was the occasion in which occidental philosophy made a substantive dismissal of common sense also of that action in public sphere that was essential to the Greek Classical thinking, and that is also on the grounds of European comprehension of a politics construed on the deliberative model.

Keywords: Arendt, Maclntyre, Public sphere, Truth, Political freedom

\section{L'utilità di un confronto fra Arendt e Maclntyre}

Pur sviluppandosi fra una varietà di temi non sempre contigui e nonostante alcuni non trascurabili ripensamenti registratisi nel corso degli anni, a partire almeno 
da Against the Self-Images of the Age ${ }^{1}$ l'opera di Alasdair Maclntyre non è contraddistinta da nette cesure o da radicali riposizionamenti. Nel suo complesso essa ha saputo mantenersi coerente rispetto al bisogno di dare voce a un disagio profondo relativo ai compiti della filosofia e ai modi del fare ricerca che è arrivato a completa maturazione sul finire del secolo scorso. In linea con le intenzioni annunciate in After Virtue, Maclntyre ha infatti cercato in tutti i suoi scritti, anche quando affronta nelle varie occasioni problemi specifici in buona parte diversi, di difendere la tesi generale secondo la quale «genuine objective and impersonal moral standards can in some way or other be rationally justified, even if in some cultures at some stages the possibility of such rational justification is no longer available $»^{2}$.

Proponendo un confronto ragionato, anche se comprensibilmente circoscritto a un numero ridotto di temi, fra la riflessione di MacIntyre e il pensiero di Hannah Arendt, vorrei contribuire alla comprensione di che cosa, nell'opera del pensatore scozzese, si debba oggi tentare di mantenere, se non anche di valorizzare. Per questo mi richiamerò innanzitutto ai motivi per cui Arendt non ha mai accettato che un vero o presunto ritorno a una qualche tradizione filosofica potesse risolvere i tanti problemi nati al seguito dei soggettivismi e dei prospettivismi moderni, riassumibili nella considerazione che la modernità è stata l'occasione con cui la filosofia occidentale ha preso un sostanziale congedo sia dal common sense sia da quell'azione nella sfera pubblica che era essenziale al pensiero greco classico e che pure si trova alla base della concezione europea di una politica ispirata al modello deliberativo. Dal punto di vista di Arendt tanto l'etica antica quanto quella medievale sono state infatti sostituite inizialmente da una visione produttivistica del mondo, a sua volta superata in tempi più recenti da una concezione che dell'essere umano privilegia gli aspetti meramente biologici. Questo si dovrebbe soprattutto alla discontinuità che si è verificata con l'imporsi della scienza sperimentale, la quale in meno di trecento anni ha portato

\footnotetext{
${ }^{1}$ A. Maclntyre, Against the Self-Images of the Age. Essays on Ideology and Philosophy, London, Duckworth, 1971.

${ }^{2}$ Id., After Virtue. A Study in Moral Theory, University of Notre Dame Press, Notre Dame, 2007³ , p. 19. 
l'essere umano, grazie alla sua acquisita capacità tecnica di obbligare la natura a svolgere alcuni processi altrimenti impossibili sul nostro pianeta, a potersi idealmente collocare al di fuori del mondo, e che perciò rende impossibile percorrere a ritroso la vicenda che pure contiene anche i motivi della nostra parziale discendenza intellettuale dall'Atene di Platone e di Aristotele. Non sarebbe perciò di alcuna utilità cercare di tornare a modi di vita conformati a visioni unitarie, ma ormai tramontate, del mondo. Ciò che si può raccomandare è, al massimo, una reinterpretazione di elementi particolari di quelle antiche visioni unitarie, per un loro impiego in forme necessariamente nuove.

Metterò anche in evidenza come il nucleo della divaricazione riscontrabile fra il pensiero di Arendt e quello di MacIntyre si debba a una diversa valutazione che l'una e l'altro riservano al concetto di convivenza politica e al determinarsi nella storia umana di ciò che, prima della sua attuazione, appariva incerto o addirittura imprevedibile. Mostrerò innanzitutto come questa imprevedibilità diventi secondo Arendt, in particolare per mezzo delle nozioni di action e process, condizione irrinunciabile al costituirsi stesso di ogni forma di vita umana associata e organizzata all'insegna della politica, poi procederò evidenziando come per MacIntyre quella stessa imprevedibilità, soprattutto quando si manifesta in ciò che è definito come «most striking feature of the [...] interminable character ${ }^{3}$ dei dibattiti contemporanei su temi di interesse morale, tenda invece a rappresentare un'occasione concessa al prodursi di disaccordi che indeboliscono fin dalle loro fondamenta la costruzione di una comunità umana coesa e l'istituzione di una convivenza civile razionalmente orientata.

Queste considerazioni mi permetteranno inoltre di richiamare quello che giudico il miglior risultato conseguito da Maclntyre almeno fino a Three Rival Versions of Moral Enquiry ${ }^{4}$, consistente nella sua descrizione di come vadano condotti $\mathrm{i}$

\footnotetext{
${ }^{3} / v i$, p. 6.

${ }^{4}$ A. Maclntyre, Three Rival Versions of Moral Enquiry. Encyclopædia, Genealogy, and Tradition, University of Notre Dame Press, Notre Dame, 1990. Con ciò non intendo sostenere che il successivo Dependent Rational Animals. Why Human Beings Need the Virtues (Carus Publishing Company, Chicago, 1999) contraddica quanto si trova nelle pubblicazioni precedenti, ma soltanto che i temi affrontati in
} 
confronti fra tradizioni in reciproca competizione, di quali siano i criteri da soddisfare perché gli esiti di questi confronti siano razionalmente giustificabili e di come rientri in tutto questo la necessità di lasciare adeguato spazio alla mancanza di conclusioni comportata dall'adozione di un metodo dialettico di matrice aristotelica. Proprio quest'ultimo passaggio mi darà modo di precisare ancora meglio quali differenze siano riscontrabili fra l'uso arendtiano e l'uso fatto da Maclntyre della nozione di interminabilità della discussione.

Si può perciò iniziare proprio da un esame della riflessione di Arendt, per poi far meglio risaltare, grazie ai contrasti che si innescano fra essa e le proposte avanzate da Maclntyre, alcune fra le più notevoli specificità di queste ultime ${ }^{5}$.

\section{Attività, attualità e sfera pubblica}

In The Human Condition ${ }^{6}$ Arendt ordina i diversi modi della condotta umana, ricordando che l'attività, distinta dapprima e per lo più nelle tre articolazioni fondamentali di labor, work e action, è vista come una condizione di base perché si possa parlare di una vita autenticamente umana. Mentre l'attività declinata come labor restituisce solamente l'intervallo entro cui la vita mostra la propria estensione biologico-metabolica, sono le forme di attività differenziate in work e action a poter essere ritenute, insieme, il tratto veramente caratteristico dell'essere umano, inteso come un vivente che esiste in un mondo il quale, se non fosse per l'attività umana concepita nella sua multiformità, sarebbe ricevibile in tutte le sue manifestazioni soltanto in maniera passiva, esattamente come pare avvenire agli animali non umani. È per questo che "The human sense of reality demands that men actualize the sheer

quest'ultima monografia si aggiungono al resto della produzione di Maclntyre in modi che non possono dirsi scontati e che le impongono una prospettiva inedita, complicandone l'immagine complessiva in una misura che meriterebbe attenzione, ma che io in questa sede non potrò approfondire.

${ }^{5}$ Dati i modi e gli scopi del mio confronto fra Arendt e Maclntyre, l'operazione in cui mi impegnerò non potrà essere considerata analoga a quella condotta da Stephen Mulhall nel suo Liberalism, Morality and Rationality: Maclntyre, Rawls and Cavell, pubblicato in J. Horton and S. Mendus, After Maclntyre. Critical Perspectives on the Work of Alasdair Maclntyre, Polity Press, Cambridge, 1994, pp. 205-224.

${ }^{6} \mathrm{H}$. Arendt, The Human Condition, The University of Chicago Press, Chicago and London, $1998^{2}$. 
passive giveness of their being, not in order to change it but in order to make articulate and call into full existence what otherwise they would have to suffer passively anyhow ${ }^{7}$. Considerate una alla volta, la forma detta work designa infatti ogni rottura dei vincoli imposti dal mondo naturale operata dall'essere umano attraverso la produzione di oggetti artificiali, mentre quella indicata come action si svolge «directly between men without the intermediary of things or matter ${ }^{8}{ }^{8}$, esaltando la condizione umana grazie alla completa immersione negli scambi interpersonali e lasciando fuori ogni relazione con ciò che non è umano.

È soprattutto per il tramite della action che si può accedere al dominio in cui trova ospitalità la migliore forma di convivenza di cui gli esseri umani abbiano mai fatto esperienza, consistente in una conciliazione fra uguaglianza politica e libertà capace di armonizzare le differenze rintracciabili fra diversi attori sociali, senza però che queste siano eliminate sotto l'urto di forze soverchianti. È inoltre sempre grazie alla action che si può dire che: 1) un'esistenza umana non è affatto sovrapponibile alla vita biologica di un organismo, perché la prima è portatrice di contenuti e implicazioni che mancano completamente alla seconda; 2) la condizione del trovarsi in vita e quella dell'essere mortali non sono sufficienti, da sole, a riflettere la specificità di un umano stare nel mondo e possono, anzi, ostacolare ogni riflessione sull'etica, rimandando a ordini esclusivamente inferiori, perché indistintamente naturali, oppure esclusivamente superiori, in quanto connotati da un'impossibilità a comunicare con gli avvenimenti del mondo. Da ciò segue che l'uguaglianza politica non si presta né a interpretazioni che vadano nel senso di una sua naturalizzazione estrema, né a trattamenti che rinviino, quali fonti per una sua legittimazione, a fenomeni tipici della fede in religioni rivelate e della distanza che per queste si stabilisce fra l'umana terrestrità e la celeste potenza divina.

\footnotetext{
${ }^{7} / v i$, p. 208.

${ }^{8} / v i$, p. 7.
} 
Political equality [...] is the very opposite of our equality before death, which as the common fate of all men arises out of the human condition or of equality before God, at least in its Christian interpretation, where we are confronted with an equality of sinfulness inherent in human nature. In these instances, no equalizer is needed because sameness prevails anyhow; by the same token, however, the actual experience of this sameness, the experience of life and death, occurs not only in isolation but in utter loneliness, where no true communication, let alone association and community, is possible. From the viewpoint of the world and the public realm, life and death and everything attesting to sameness are non-worldly, antipolitical, truly transcendent experiences ${ }^{9}$.

Considerata l'importanza dell'attualizzazione perché si possa comprendere come la condizione umana non sia definita né dalla passività né da forme di uguaglianza extra-politiche che appiattirebbero ogni esperienza mondana, diventa più facile comprendere anche perché, per Arendt, «This actualization resides and comes to pass in those activities that exist only in sheer actuality ${ }^{10}$. Si cerchino quelle attività che si svolgono soltanto o in buona misura nel modo dell'attualità e si potrà anche capire come avvenga che attualizzazione e politica siano termini che partecipano a un unico discorso. A questo proposito non potrà infatti soddisfare l'attività intesa come work, perché questa, pur essendo sempre costretta ad attualizzarsi, ha il suo senso nella produzione di qualcosa che si trova al di fuori di essa e che perciò non condivide la sua stessa natura.

While the strength of the production process is entirely absorbed in and exhausted by the end product, the strength of the action process is never exhausted in a single deed but, on the contrary, can grow while its consequences multiply; what endures in the realm of human affairs are these processes, and their endurance is as unlimited, as independent of the perishability of material and the mortality of men as the endurance of humanity itself. The reason why we are never able to foretell with certainty the outcome and end of any action is simply that action has no end ${ }^{11}$.

\footnotetext{
${ }^{9}$ Ivi, p. 215.

${ }^{10}$ Ivi, p. 208.

11 Ivi, p. 233.
} 
Si può quindi comprendere ancora meglio perché, fra labor, work e action, Arendt abbia riservato il posto più elevato a quest'ultima forma di attività, grazie alla quale diventano possibili rapporti diversi da quelli intrecciati con il mondo naturale e con quello artificiale, specialmente a causa della loro durata e della portata delle loro conseguenze. Lo aveva del resto già ben visto Aristotele quando «in his political philosophy, is still well aware of what is at stake in politics [...], that "work" here is no work product but - ecco di nuovo il motivo fondamentale - exists only in sheer actuality ${ }^{12}$.

Va però aggiunto che, per il tramite dell'azione e per il suo venire a esistenza soltanto nell'attualità delle vive relazioni fra esseri umani, si mostra anche con chiarezza come la politica non possa fare a meno della presenza di una pluralità di soggetti: se si è soli, non ci si può impegnare in alcuna attività intesa come action. Perché l'esperienza politica sia possibile, è perciò necessario che la condizione umana sia vista al plurale ${ }^{13}$.

Una volta che si sia compreso che la politica va ricondotta all'attualità dell'azione portata all'interno della convivenza fra una pluralità di soggetti, resta ancora da capire quale sia la concreta espressione di questa forma di attività. A questo proposito si deve dire che acquista un grande peso per gli esseri umani il fatto che il loro trovarsi nel mondo sia segnato nei suoi aspetti più profondi dalla caducità di tutte le intenzioni e di tutte le opere, al punto che un'enorme quantità di sforzi è stata indirizzata fin dall'antichità alla costruzione di qualcosa che potesse durare, così da contrastare il destino che attende ogni esistenza, che è quello - per restare in particolare al pensiero greco - di ridursi soltanto a un'ombra, al di là di ogni piccola o grande fatica compiuta in vita. Per non perdere di vista la dimensione individuale, la gloria mondana conquistata presso i propri amici e compagni, e poi tramandata indefinitamente da una generazione all'altra, costituisce allora il migliore esempio di ciò a cui, nella Grecia classica, un uomo libero avrebbe plausibilmente aspirato durante

12 Ivi, pp. 206-207.

${ }^{13}$ Ivi, p. 7: «men, not Man, live on the earth and inhabit the world». 
la propria esistenza. La misura delle sue realizzazioni veniva infatti posta in qualche modo in una relazione di proporzionalità diretta con la possibilità che aveva di conquistarsi un ricordo imperituro presso i familiari, i compagni, i concittadini. II valore militare rappresentava il primo fra i mezzi utili a maturare questa conquista, eppure non sempre si poteva avere l'occasione di farsi valere in uno scontro armato. All'impegno in guerra si poteva però trovare un'alternativa, come la storia della stessa civiltà greca ha ben mostrato: se non proprio una grande impresa bellica, poteva infatti essere una primazia nella vita pubblica a consentire a un cittadino di ottenere la fama tanto desiderata. Perché questo potesse accadere era però necessario che si trovassero soddisfatte tutte le condizioni che consentivano lo stabilirsi di uno spazio pubblico frequentabile da parte di chi si trovasse ammesso nel numero degli uomini liberi e uguali. L'azione serviva propriamente, allora, sia a tenere aperto questo spazio sia a fornirlo, nella forma della materia politica, di contenuti precisi, i quali si esprimevano tipicamente attraverso la forma del discorso. È dunque l'azione che si esprime nel discorso portato nello spazio pubblico a consentire e insieme manifestare nella maniera più propria il complesso di relazioni che intercorrevano fra uomini liberi, riempiendo di senso la vita cittadina.

Non deve però sfuggire, a questo punto, che la necessità dell'azione conteneva in sé i germi di una contraddizione, perché la polis non poteva evitare, da una parte, di cercare di ordinarsi tramite la costituzione di istituzioni durevoli, e allo stesso tempo, dall'altra, doveva anche riuscire a farsi forte di tutte le iniziative introdotte nello spazio pubblico e che per definizione potevano rappresentare novità potenzialmente dannose per quelle stesse istituzioni. È per questa ragione che Arendt scrive che "Exasperation with the threefold frustration of action - the unpredictability of its outcome, the irreversibility of the process, and the anonymity of its authors - is almost as old as recorded history ${ }^{14}{ }^{14}$, ed è poi a causa di questa esasperazione che la

\footnotetext{
${ }^{14} \mathrm{Ivi}$, p. 220. Per vedere come l'azione, a causa del suo mettere in moto processi le cui conseguenze sono incalcolabili a priori, possa essere considerata una colpa personale e perciò anche avvertita come un peso difficile da portare, cf. Ivi, p. 233-234.
} 
riflessione sulla politica è spesso sembrata vicina a conoscere momenti di arresto definitivi. Arendt evidenzia in questo modo come la ricerca di un ordine politico che non fosse toccato dal male della transitorietà sia stata comunque contraddistinta da un vizio d'origine di cui può rendersi meglio conto chi sia nato in un mondo contraddistinto dal pluralismo delle concezioni politiche, in cui queste si trovino in aperta concorrenza le une rispetto alle altre, piuttosto che in un mondo culturalmente più coeso, come era quello degli antichi greci. Questo vizio d'origine si colloca, per l'appunto, al livello della natura stessa dell'azione, la quale non può condurre verso la stabilità, perché porta comunque con sé il nuovo, l'imprevisto, ciò il cui arrivo non era stato contemplato e che scompagina quanto era stato assunto fino a quel momento come garantito. Fin dai suoi esordi la riflessione sulla politica è stata tanto sensibile a questa difficoltà che «Escape from the frailty of human affairs into the solidity of quiet and order has in fact so much to recommend it that the greater part of political philosophy since Plato could easily be interpreted as various attempts to find theoretical foundations and practical ways for an escape from politics altogether ${ }^{15}$.

Eppure, se una politica deve esserci, essa deve accettare non solo che le realizzazioni umane passino, ma che siano scardinate proprio dall'inatteso, da ciò che manifesta la propria urgenza per il solo fatto di nascere, di iniziare, di introdursi come mutamento e crescere come processo. Se ci si volesse mettere al riparo da tutto questo, ci si ritroverebbe in una situazione di immobilità che negherebbe aspetti essenziali della condizione umana, in particolare quelli connessi alla natalità: finché continueranno a darsi nascite umane, alimentando così la pluralità delle prospettive, il movimento impresso al mondo da parte degli esseri umani potrà infatti conservarsi, ed è per questa ragione che si può anche dire che "Limitations and boundaries exist within the realm of human affairs, but they never offer a framework that can reliably withstand the onslaught with which each new generation must insert itself. The frailty of human institutions and laws and, generally, of all matters pertaining to men's living

${ }^{15} / v i$, p. 222. 
together, arises from the human condition of natality and is quite independent of the frailty of human nature» ${ }^{16}$; oppure che: "The calamities of action all arise from the human condition of plurality, which is the condition sine qua non for that space of appearance which is the public realm. Hence the attempt to do away with this plurality is always tantamount to the abolition of the public realm itself $»^{17}$. È alla luce di queste considerazioni che si può comprendere fino in fondo anche l'affermazione che "The only indispensable material factor in the generation of power is the living together of people ${ }^{18}$, e che è grazie alla possibilità che gli esseri umani hanno di apparire sulla scena pubblica e di intrattenervi relazioni che la stessa politica può diventare esperienza veramente umana.

\section{Società di massa, alienazione dal mondo e rischi per la libertà politica}

Alcune distinzioni valide per l'antichità non cessano di restare utili per interpretare tempi più vicini ai nostri, potendoci inoltre aiutare a identificare i tratti più qualificanti dell'odierna condizione umana e a capire per quali ragioni i mali dell'epoca contemporanea non possono essere esorcizzati attraverso tentativi di riesumazione del passato.

Secondo Arendt il punto centrale di una riflessione adeguata intorno alla politica e alla convivenza umana non può non riguardare la prevalenza che la dimensione sociale ha assunto nel corso della modernità sia sulla dimensione privata sia su quella pubblica, lasciando l'umanità contemporanea nella condizione di servire da perfetto oggetto d'indagine per la scienza statistica e di essere variamente incasellata all'interno di continue compilazioni, estese a quasi ogni ambito dell'esistenza. Il conformismo sociale, che è infine diventato il carattere distintivo della

\footnotetext{
${ }^{16} / v i$, pp. 190-191.

${ }^{17}$ Ivi, p. 220. Per apprezzare come il nesso che lega l'azione alla pluralità degli esseri umani possa far prevalere le ragioni della vita su quelle della morte, oltre che conferire un andamento lineare alla temporalità umana, si veda Ivi, p. 246: «[...] without action and speech, without the articulation of natality, we would be doomed to swing forever in the ever-recurring cycle of becoming».

${ }^{18} / \mathrm{vi}, \mathrm{p} .201$.
} 
vita in comune, porta necessariamente a una diminuzione in estensione e numero di tutti quei comportamenti individuali che sono per qualche verso in difformità rispetto al modello dominante di comportamento, il quale si fa sempre più forte man mano che la quantità di persone ammesse nella società aumenta. In questo modo le eccezioni tendono alla scomparsa, confondendosi in una quotidianità uniforme, che non permette che si rendano più riconoscibili opzioni individuali di senso o che la politica, in contrasto con l'esistenza esclusivamente privata, possa riuscire a conservare almeno la vitalità dell'antica ricerca di una durata indefinita per i prodotti delle attività umane.

Arendt nota a questo proposito come «What makes mass society so difficult to bear is not the number of people involved, or at least not primarily, but the fact that the world between them has lost its power to gather them together, to relate and to separate them ${ }^{19}$. Ciò che è andato smarrito è dunque il mondo fra le persone, che serviva non soltanto a unire, ma anche a separare. Relazione e separazione - si potrebbe anche parlare di vicinanza e separazione - sono infatti due aspetti compresenti alla medesima condizione e la loro mancanza, tendendo a rendere indistinguibili i confini sia dei soggetti sia degli oggetti che si trovano nel mondo, rende anche estremamente difficile interpretare il tempo presente e opacizza ogni sguardo che si voglia rivolgere verso un futuro immaginato come capace di ospitare scopi determinati. Nel tempo in cui le relazioni umane stanno conoscendo questo schiacciante dominio della dimensione sociale - che è anche il tempo in cui homo faber è stato spodestato da homo laborans - né alcuna vera o presunta «common nature of men» né "the unnatural conformism of a mass society» ${ }^{20}$ possono opporsi alla perdita della realtà, la quale però rappresenta per le attività umane, necessariamente alimentate dalla varietà concorrente delle molteplici prospettive, un motivo di tradimento della loro destinazione autentica. Infatti, "Only where things can be seen by many in a variety of aspects without changing their identity, so that those who are gathered around them know they see sameness in utter diversity, can worldly reality

${ }^{19}$ Ivi, pp. 52-53.

${ }^{20} / \mathrm{vi}, \mathrm{p} .58$. 
truly and reliably appear ${ }^{21}$. È anche per questo che lo strapotere della società, tendendo a una cancellazione della sfera pubblica, porta verso una fusione dei molti in un'unità indistinta, piuttosto che a un'aristotelica uguaglianza di soggetti capaci di contribuire, ognuno dalla propria distinta prospettiva e per mezzo della propria singolare abilità, alla vita politica. Si arriva con ciò all'emergere di forme generalizzate di perdita d'identità personale che sono l'opposto di ogni comunanza d'intenti capace di concorrere a fondare etiche, dunque esistenze umane associate e fornite di senso.

\begin{abstract}
The sameness prevailing in a society resting on labor and consumption and expressed in its conformity is intimately connected with the somatic experience of laboring together, where the biological rhythm of labor unites the group of laborers to the point that each may feel that he is no longer an individual but actually one with all others. [...] It is therefore quite true that for the animal laborans "labor's sense and value depend entirely upon the social conditions," that is, upon the extent to which the labor and consumption process is permitted to function smoothly and easily, independent of "professional attitudes properly speaking"; the trouble is only that the best "social conditions" are those under which it is possible to lose one's identity ${ }^{22}$.
\end{abstract}

Ciò che qui interessa delle riflessioni che si concludono affrontando il tema della perdita di identità personale è che la società in cui questa stessa perdita si origina è largamente incompatibile con la definizione di una politica connessa alla sfera pubblica. La fusione in una sorta di corpo unitario di tutte le forze univocamente indirizzate da parte delle società di massa verso la perpetuazione di una cieca sopravvivenza biologica porta con sé anche l'eliminazione della possibilità stessa di uno spazio politico propriamente inteso, vale a dire un luogo di conciliazione delle differenze individuali presenti fra appartenenti alla stessa comunità. È questa la ragione per cui:

This unitedness of many into one is basically antipolitical; it is the very opposite of the togetherness prevailing in political or commercial communities, which - to take the Aristotelian example - consist not of an

21 Ivi, p. 57.

22 Ivi, p. 214. 
association (koinonia) between two physicians, but between a physician and a farmer, "and in general between people who are different and unequal." The equality attending the public realm is necessarily an equality of unequals who stand in need of being "equalized" in certain respects ad for specific purposes ${ }^{23}$.

La distanza che per noi si è oggi determinata dal tempo in cui sfera pubblica e koinonia realizzavano nella maniera più completa la comunità politica non si è prodotta senza importanti discontinuità. Al contrario, perché questa distanza si approfondisse nella maniera sperimentabile all'interno delle società contemporanee è servito il passaggio attraverso l'intera modernità, portatrice a sua volta di cambiamenti estremamente rilevanti.

La rottura dei legami con una concezione aristotelica della politica si è infatti resa già definitiva con quanto avvenuto in Occidente nel periodo che va da XVII al XIX secolo, perché è in questo tempo che si è realizzata, in modi che in epoche precedenti non erano neanche immaginabili, quella che Arendt chiama un'alienazione dal mondo. Per il tramite della scienza galileiana e della sua capacità tecnica, via via accresciuta sempre di più, di spostare l'osservatore umano oltre i limiti del mondo abitato, fino allo spazio cosmico, è arrivata la conquista di «a cosmic standpoint outside nature itself $»^{24}$ che ha messo fine alla familiarità dell'essere umano con il suo mondo, addirittura estraniandolo da esso. Lo scienziato, figura cardine della modernità, ha ormai i mezzi per accordare le proprie visioni matematizzanti a estensioni di portata addirittura universale, giungendo tra l'altro a scorgere innegabili similitudini tra gli ambiti del sommamente grande e quelli del sommamente piccolo. È per questo motivo che, rileggendo in una sintesi estrema una vicenda intellettuale plurisecolare, Arendt nota come:

It would be folly indeed to overlook the almost too precise congruity of modern man's world alienation with the subjectivism of modern philosophy, from Descartes and Hobbes to English sensualism, empiricism, and

${ }^{23}$ Ivi, pp. 214-215.

${ }^{24}$ Ivi, p. 265. 
Non si giudichi però - come già detto - che la scoperta di motivi di fondo trasversali ai diversi orientamenti della filosofia moderna possa da sola giustificare la proposta di pure inversioni di rotta rispetto al cammino percorso dalla civiltà europea negli ultimi quattro secoli, perché

\begin{abstract}
it would be equally foolish to believe that what turned the philosopher's mind away from the old metaphysical questions toward a great variety of introspections [...] was an impetus that grew out of an autonomous development of ideas, or, in a variation of the same approach, to believe that our world would have become different if only philosophy had held fast to tradition ${ }^{26}$.
\end{abstract}

Sembra difficile poter immaginare una critica più diretta a un tentativo che sembra ricalcare in alcuni tratti essenziali quello intrapreso e lungamente perseguito proprio da Maclntyre, vale a dire il proporre un ritorno alla tradizione, o per lo meno a una pratica filosofica che porta al suo interno tutti gli elementi distintivi di una tradizione ben definita.

A posteriori dell'impresa intellettuale moderna, definibile a partire dall'impronta che la scienza ha lasciato su di essa, l'invito di cui Arendt si fa portatrice nella sua riflessione è invece quello a trovare nella nostra epoca, segnata da insicurezze di un genere mai conosciuto prima, un nuovo spazio per il pensiero. L'irreversibilità del cambiamento cui la civiltà europea è andata incontro nei circa duemilaquattrocento anni che ci separano dal tempo di Platone non può infatti farci giudicare praticabile una semplice riesumazione della vita contemplativa o un suo ritorno al rango a lei riservato da parte di Aristotele. Al contrario, in questo senso la vita contemplativa è ormai davvero irrecuperabile. Ciò che invece occorre cercare è una possibilità inedita per il pensiero, perché non sembra né fatale né realistico che

${ }^{25}$ Ivi, p. 272.

${ }^{26}$ Ivi, pp. 272-273. 
esso sia lasciato al servizio della fabbricazione, dunque riservato a funzioni solamente strumentali, quando la fabbricazione stessa vede oggi messo in grave pericolo il suo rilievo ${ }^{27}$.

\section{Il pensiero come attività e il problema della libertà}

Si scopre a questo punto che The Human Condition è un'opera che si presta utilmente anche a una lettura condotta a ritroso, perché sono le sue ultime pagine a poterne mostrare con efficacia alcune intenzioni di fondo che sono lasciate per il resto quasi completamente sotto traccia. Sono d'altronde le stesse pagine che suggeriscono meglio di tante altre come The Human Condition vada collocata rispetto al complesso della produzione arendtiana, permettendo di constatare, per esempio, come l'attenzione di Arendt per la filosofia pratica non sia sconfessata né minimizzata dai successivi approfondimenti riguardanti le «mental activities» e ospitati soprattutto in The Life of the Mind ${ }^{28}$. Se per la sua quasi totalità The Human Condition si occupa di come le diverse attività umane si siano intrecciate in una competizione iniziata nell'antichità e durata fino alla compiuta realizzazione della condizione moderna, e di come I'homo laborans abbia infine conquistato un primato che era stato dapprima detenuto da coloro che agivano nello spazio pubblico e che poi sembrava definitivamente passato nelle abili mani - è il caso di dirlo - dell'homo faber, il testo si chiude soltanto dopo aver compiuto altri due passi, fra loro connessi. Il primo di questi consiste nell'affermare che anche il pensiero è attività e che anzi, proprio quanto al suo grado di «sheer activity» ${ }^{29}$, esso supera tutte le altre attività umane; il secondo segue da vicino il richiamo alla natura di attività posseduta dal pensiero, coniugandolo con il riconoscimento che esso «is still possible, and no doubt actual, wherever men

\footnotetext{
${ }^{27}$ Ivi, p. 307: «No other capacity [...] stood to lose as much through modern world alienation and the elevation of introspection into an omnipotent device to conquer nature as those faculties which are primarily directed toward the building of the world and the production of worldly things».

${ }^{28} \mathrm{H}$. Arendt, The Life of the Mind, Harcourt Brace \& Company, New York, 1978, p. 3.

${ }^{29}$ H. Arendt, The Human Condition, p. 325.
} 
live under conditions of political freedom ${ }^{30}$. Questo passo è inoltre rafforzato dall'affermazione che segue immediatamente, secondo cui "Unfortunately, and contrary to what is currently assumed about the proverbial ivory-tower independence of thinkers, no other human capacity is so vulnerable, and it is in fact far easier to act under conditions of tyranny than it is to think». Accade dunque che il pensiero si veda attribuita da Arendt la qualifica di attività suprema e preveda come propria condizione indispensabile la libertà politica.

Come già accennato, quando si guardi a opere successive a The Human Condition si vedrà come molti dei temi affrontati in quello studio tornino a essere trattati e approfonditi in vario modo, o per motivi di stretta continuità con quanto lì si trovava affermato, o in ragione di esigenze legate a situazioni particolari, ma con quello facilmente raccordabili. Insieme alle continuità rintracciabili fra The Human Condition e The Life of the Mind - che fanno dire che il programma di lavoro sviluppato in quest'ultima si trovava già tratteggiato per alcuni dei suoi punti fondamentali, e con circa vent'anni di anticipo, nell'altra -, si può anche notare con quale partecipazione, in occasione del suo discorso di ringraziamento per il conferimento nel 1959 del premio intitolato a Lessing, Arendt descriva la considerazione in cui erano tenute, nella polis greca, sia la possibilità di fare discorsi in pubblico sia l'amicizia fra cittadini liberi, e come in quella sede si soffermi sul fatto che la civiltà della Grecia classica non poteva concepire alcuna amicizia umana che non fosse anche portatrice di un valore politico, che non si trovasse cioè completamente inserita all'interno della sfera pubblica ${ }^{31}$.

Si può dunque dire che fin da The Human Condition attività pratiche, spazio pubblico e relazioni fra esseri umani concorrono, secondo Arendt, alla formazione di un intreccio che va osservato da vicino per poter capire come la libertà politica sia necessaria tanto alla convivenza politicamente organizzata quanto al pieno esercizio di un pensiero che non rifugga da un rapporto con il mondo. Proprio il distacco dagli avvenimenti del mondo rappresenta infatti una tentazione particolarmente forte per

${ }^{30}$ Ivi, p. 324.

${ }^{31}$ H. Arendt, Men in Dark Times, Harcourt Brace \& Company, New York, 1968, pp. 24-25. 
chi, tenendo alla propria indipendenza di pensiero, trova che questa sia messa in pericolo dalla situazione politica o dalla difficoltà dei tempi in cui vive. La libertà entra del resto in diversi ambiti e in alcuni essa è più ravvisabile che in altri, come capita per esempio nel caso del movimento o nel caso della parola. Non può quindi stupire che, qualora la libertà di movimento venga a mancare - e questo può facilmente avvenire se lo spazio pubblico si restringe o si annulla -, si cerchi almeno di salvarne altre forme, fra le quali va elencata prima di altre proprio la libertà di pensiero ${ }^{32}$.

La ricerca di un ritiro dalle cose del mondo per trovare rifugio nel puro pensiero è stata così un'opzione che la filosofia ha sempre tenuto in considerazione, anche perché ha spesso giudicato il puro pensiero come il culmine della potenza esprimibile dalla mente umana. La contemplazione, che è il modo tradizionalmente codificato di indicare il pensiero nella sua massima applicazione, comporta però che la rottura dei rapporti con il mondo coinvolga anche la partecipazione alla vita politica e questo spiega almeno in parte perché una scelta a suo favore sia spesso apparsa dolorosa e comunque riservata a pochi. Chi avesse voluto farsi conoscere come buon cittadino della polis non avrebbe potuto prendere in considerazione la via della contemplazione senza confrontarsi con il timore che almeno una parte dei membri della sua comunità d'appartenenza lo guardasse con sospetto o arrivasse a giudicarlo addirittura un nemico. Che cosa si può però dire di chi oggi, non accettando la fatica di contribuire a tenere aperto lo spazio pubblico, si allontanasse dal mondo allo scopo di frequentare soltanto un pensiero puro? La sua scelta avrebbe maggiori giustificazioni della stessa scelta compiuta nella Grecia classica? Si tratta evidentemente di questioni decisive, anche perché potrebbe darsi che l'opzione a favore della contemplazione portasse, magari in maniera involontaria, a fare il gioco delle forze che spingono verso il conformismo di massa o verso l'affermazione di poteri dispotici, oppure rivelasse soltanto che si è già vittima di quelle stesse forze o di quegli stessi poteri.

${ }^{32}$ Cf. Ivi, p. 9. 
A questo proposito Arendt nota però che il disagio che si prova di fronte alla secca alternativa fra stare attivamente nel mondo o allontanarsene in cerca di un più elevato tipo di vita potrebbe essere per alcuni importanti versi superato grazie all'osservazione che il pensiero non è passività, come tanta parte della tradizione ha sostenuto, bensì attività, sebbene un'attività di un tipo particolare. Ad aiutarci a capirlo potrebbe essere la distinzione introdotta da Kant fra Vernunft (reason) e Verstand (intellect), corrispondente alla distinzione fra una facoltà della mente che cerca il significato delle cose e una facoltà che ne cerca invece la verità (truth $)^{33}$, sebbene si debba ammettere, per Arendt, che il suo stesso proponente non sembri averne compreso appieno tutte le implicazioni. Infatti «The reason neither Kant nor his successors ever paid much attention to thinking as an activity and even less to the experiences of thinking ego is that, all distinctions notwithstanding, they were demanding the kind of results and applying the kind of criteria for certainty and evidence that are the results and criteria of cognition ${ }^{34}$. Ecco allora perché si è potuto generare e conservare tanto a lungo il tradizionale equivoco secondo cui il pensiero sarebbe passivo: perché, in quanto ricerca di significato, «The thinking activity [...] leaves nothing [...] tangible behind $»^{35}$. Occupandosi dei soli significati, il pensiero non produce né fabbrica alcunché, non accumula dati o informazioni e neppure si stratifica, visto che ciò che in esso è venuto prima ha per lo più forme molto volatili, e quindi può servire solo con molta difficoltà da solida base per ciò che viene dopo. Scambiare il pensiero per una manifestazione dello spirito puramente ricettiva equivarrebbe però a commettere un errore e il riconoscerlo può fare finalmente dire, in contrasto con la convinzione tradizionale, che "the need to think can therefore never be stilled by the

\footnotetext{
${ }^{33} \mathrm{H}$. Arendt, The Life of the Mind, p. 14: «the distinguishing of the two faculties, reason and intellect, coincides with a distinction between two altogether different mental activities, thinking and knowing, and two altogether different concerns, meaning, in the first category, and cognition, in the second». Cf. inoltre Ivi, pp. 5-15.

${ }^{34} \mathrm{Ivi}$, p. 15.

35 Ivi, p. 62.
} 
insights of "wise men" ${ }^{36}$, e che una voluta distanza dal mondo non può più essere pacificamente presa per il fine più alto cui la filosofia debba aspirare.

\section{MacIntyre: alla ricerca di una proposta costruttiva}

Fino a qui si è visto come per Hannah Arendt la condizione umana non possa essere descritta con efficacia se non si tiene conto della varietà delle attività umane, comprendendo fra esse non soltanto l'azione, ma anche il pensiero, e sapendo che queste attività sembrano resistere a ogni tentativo che sia diretto a ricondurle all'interno dell'immagine di una condotta pienamente coerente in quanto uniformata a un solo, incontestabile principio pratico. Questa posizione diventa inoltre ancora più chiara quando si attribuisce la giusta importanza sia all'elemento della novità sempre insorgente introdotta dalla natalità sia all'irrinunciabile pluralità delle esistenze e delle prospettive umane ${ }^{37}$.

Venendo ora all'esame della proposta di Maclntyre, si potrebbe anticipare che le tante differenze che vi si ritrovano rispetto alla filosofia di Arendt si devono a un disaccordo di natura fondamentale relativo a che cosa debba essere richiesto al pensiero e a quali siano di conseguenza i compiti di un filosofo e quelli di un individuo qualunque. Per Maclntyre, infatti, «The philosophical theorist has to enquire: What is the good specific to human beings? Each individual has to enquire: What is my good as a human being?» ${ }^{38}$, cui bisognerebbe aggiungere anche che "no true answer can be given by the philosophical theorist which is not somehow or other translatable into true answers that can be given to their practical questions by ordinary human

\footnotetext{
${ }^{36} \mathrm{lbid}$.

37 Una lettura che tenga conto di questi e di altri elementi presenti nella riflessione arendtiana adottando come proprio sfondo la teoria sociologica e politica di Weber è quella proposta in K. Breen, Under Weber's Shadow: Modernity, Subjectivity and Politics in Habermas, Arendt and Maclntyre, Ashgate, Farnham, 2012, pp. 93-150. Per vedere come la stessa prospettiva sia fatta valere anche per MacIntyre, Ivi, pp. 153-225.

${ }^{38}$ A. Maclntyre, Three Rival Versions of Moral Enquiry, p. 128.
} 
individuals, no true answers can be given to their questions by such individuals which do not presuppose some particular type of answer to the philosopher's question ${ }^{39}$.

Per quanto riguarda la necessità di riflettere sugli esseri umani intesi nella loro pluralità, dunque indagandone l'esistenza alla luce della loro compresenza e della loro convivenza, le due filosofie si dimostrano però accostabili l'una all'altra, perché in entrambe si evidenzia come non si arrivi ad alcun risultato soddisfacente se si sceglie quale proprio oggetto d'indagine l'individuo isolato, cioè privato di tutti gli aspetti di relazione che lo legano ad altri esseri umani. Questo risulta tanto più vero dopo la pubblicazione di Dependent Rational Animals, in cui Maclntyre presta un'attenzione quasi esclusiva ai rapporti di dipendenza che gli esseri umani manifestano, a vari livelli, gli uni verso gli altri, attribuendo loro un'importanza che, per la comprensione della moralità, non può non trovare un riconoscimento ${ }^{40}$.

Se però Arendt rimane attenta soprattutto a non introdurre semplificazioni che rischierebbero di falsare la complessità intrinseca alla condizione umana, Maclntyre sostiene invece che ciò che va riconosciuto quando si parla degli esseri umani è la possibilità che ciascuno di essi avrebbe di realizzare una propria unità, a patto di ammettere che tutte le unità di questo genere sarebbero ottenibili soltanto disponendo in ordine gerarchico una molteplicità di elementi distinti e accordando i propri comportamenti a quelli delle altre in base a un'etica non astratta, bensì condivisa a partire dalla sua obbedienza a sicuri criteri di razionalità. Una riflessione che fosse effettivamente all'altezza dei propri compiti dovrebbe innanzitutto andare, perciò, verso la conservazione per ogni essere umano della possibilità di vivere preservando la propria esistenza da situazioni che «would systematically infect the shared moral rules of modern societies ${ }^{41}{ }^{1}$, come sarebbero quelle prodotte da fasi storiche caratterizzate da estesa confusione intorno ai fini del vivere associato. Si

\footnotetext{
${ }^{39}$ Per vedere come le domande di interesse teorico siano del resto molto vicine a quelle cui dedicano attenzione anche i non esperti in filosofia, si veda A. Maclntyre, Whose Justice? Which Rationality?, University of Notre Dame Press, Notre Dame, 1988, pp. 174-175.

${ }^{40}$ A. Maclntyre, Dependent Rational Animals. Si vedano in particolare i capp. VII-IX.

${ }^{41}$ A. MacIntyre, Three Rival Versions of Moral Enquiry, p. 188.
} 
tratterebbe infatti di fonti di un tipo di inquinamento che investirebbe le condizioni necessarie perché i diversi rapporti umani potessero servire all'istituzione di una convivenza stabile, dunque di mali che potrebbero aprire solchi tanto ampi fra le singole esistenze da non poter essere richiusi. Se l'individuo spogliato delle sue relazioni sociali non può quindi essere assunto come l'ultimo oggetto d'indagine di alcuna riflessione filosofica che possa dirsi esaustiva, è chiaro che fra i compiti della filosofia si trova anche quello di scoprire quali siano le basi più solide su cui andrebbero costituite comunità politiche che fossero tanto più durevoli quanto più fossero capaci di accordare al loro interno le condotte dei loro membri.

Si tratta, per MacIntyre, di avere l'occasione di uscire dall'alternativa sbagliata stabilitasi per troppo tempo fra concezioni incentrate sulla nozione di relatività culturale o sociale delle etiche e concezioni incentrate sull'aspirazione a formulare verità universali, mostrando che in questo caso si opporrebbero l'uno all'altro due errori speculari: da una parte ci sarebbe chi ritiene che, a causa dell'inevitabile particolarismo sotteso a ogni etica storicamente data, riguardo alle regole della vita associata si dovrebbe rinunciare a tutte le pretese di verità; dall'altra ci sarebbe chi sostiene, proprio in nome di quelle stesse pretese di verità e del fatto che esse devono essere riconoscibili da chiunque e al di là di tutte le determinazioni di tempo e di luogo, che ogni visione adottata restando all'interno di una precisa etica o di uno specifico modo di vita sia fin dall'inizio viziata da pregiudizi ${ }^{42}$. Maclntyre sostiene invece che questa opposizione potrebbe lasciare posto a un superamento di entrambe le concezioni, se soltanto si riconoscesse, come egli stesso fa in Three Rival Versions of Moral Enquiry, che prendere consapevolmente le mosse da una tradizione particolare piuttosto che da un'altra non costituisce di per sé un modo di rafforzare il relativismo, ma può anzi portare ad accantonarlo definitivamente. A questo scopo ciò che occorrerebbe fare sarebbe portare il confronto con le tradizioni rivali sul terreno della

${ }^{42}$ Questa seconda concezione è quella che Maclntyre attribuisce in generale a tutti gli Illuministi, al di là dei tanti disaccordi nati al loro interno in merito a quali siano effettivamente i principi universali sui quali fondare un'etica razionale a prova di determinazioni storiche. Cf. A. Maclntyre, Whose Justice? Which Rationality?, p. 6. 
Ioro stessa capacità di soddisfare appieno i propri criteri di giustificazione razionale, e la tradizione che in un confronto di questo genere sapesse mostrarsi la più coerente tanto per i propri quanto per gli altrui criteri di giustificazione verrebbe dichiarata superiore alle rivali. In Whose Justice? Which Rationality? Maclntyre aveva adottato un punto di vista simile a questo quando aveva parlato di «a conception of rational enquiry as embodied in a tradition, a conception according to which the standards of rational justification themselves emerge from and are part of history in which they are vindicated by the way in which they transcend the limitations of and provide remedies for the defects of their predecessors within the history of the same tradition ${ }^{43}$ oppure quando aveva indicato che l'opposizione fra «relativist challenge» e «perspectivist challenge» è da ritenere derivata da un contrasto precedente, alimentato in modi fra loro speculari e ugualmente insufficienti, con l'Illuminismo ${ }^{44}$.

Maclntyre si è certamente impegnato a fondo nella ricerca degli assunti di partenza errati che hanno segnato fin dalla loro origine le teorie filosofiche moderne, non limitandosi, però, a esercitare soltanto un ruolo di censore. Ha infatti cercato di portare a termine un'impresa intellettuale più ambiziosa, comprensiva di un contributo distintamente propositivo. In effetti, agli inizi degli anni Settanta, dedicando una breve riflessione alle possibilità e ai limiti della politica comparata, dichiarava come: "The ultimate aim of this paper is constructive; the skepticism which infects so

\footnotetext{
${ }^{43}$ IVi, p. 7. La convinzione di Maclntyre che un confronto razionale può essere concluso con successo soltanto a partire dalla consapevole adozione di una prospettiva particolare piuttosto che collocandosi in una posizione di pretesa neutralità si trova espressa in una forma diversa anche a p. 144: «Progress in rationality is achieved only from a point of view. And it is achieved when the adherents of that point of view succeed to some significant degree in elaborating ever more comprehensive and adequate statements of their positions through the dialectical procedure of advancing objections which identify incoherences, omissions, explanatory failures, and other types of flaw and limitations in earlier statements of them, of finding the strongest arguments available for supporting those objections, and then of attempting to restate the position so that it is no longer vulnerable to those specific objections and arguments».

${ }^{44}$ Ivi, pp. 351-353. Per valutare come l'impegno profuso contro l'llluminismo, identificato come primo e maggiore obiettivo della sua critica, porti MacIntyre a ricondurre troppo sbrigativamente sotto quella denominazione tradizioni politiche distinte e non trascurabili, oscurando in questa maniera la complessità dell'elaborazione politica occidentale, si veda Ph. Pettit, Liberal/Communitarian: MacIntyre's Mesmeric Dichotomy, in J. Horton and S. Mendus, After MacIntyre, pp. 176-204.
} 
much of my argument is a means and not an end ${ }^{45}$. Osservando il contenuto delle sue pubblicazioni successive, le ultime delle quali risalenti a quasi una trentina d'anni più tardi, si può constatare come l'intento principale che egli si attribuiva in quel saggio sia rimasto immutato: offrire alternative alle posizioni di cui volta per volta, a seconda delle occasioni, evidenziava le carenze, anche per quei casi a proposito dei quali si impegnava in interventi di critica particolarmente duri.

\section{La mancanza di luoghi istituzionali designati alla discussione costruttiva}

Nel proseguire una riflessione che aveva già trovato in After Virtue una sua prima presentazione organica, Maclntyre si lamenta di un equivoco in cui sarebbero caduti alcuni suoi lettori: chi avesse interpretato quel suo libro soltanto come un tentativo di riproporre una moralità fondata sulle virtù avrebbe infatti mancato di capire che su quelle stesse virtù non può darsi un discorso completo senza che a esso sia affiancato anche un ragionamento sulla giustizia e sulle regole che contribuiscono a produrla. Con Whose Justice? Which Rationality? Maclntyre intende sgombrare il campo da questo equivoco ${ }^{46}$, legando inoltre il suo approfondimento intorno ai modi in cui diverse teorie della giustizia si trovano a competere le une con le altre a un discorso analogo, ma ancora più di fondo, sul confronto fra teorie della razionalità.

Se si cominciasse infatti dal tema della giustizia e dalla sfida che esso rappresenta per un pensiero che non voglia accettare supinamente la situazione che gli viene consegnata dall'epoca presente, caratterizzata da una contrapposizione fra tradizioni che si è fatta sterile sotto il profilo etico, ma che si proponga di arrivare piuttosto alla formulazione di una posizione razionalmente giustificabile, ci si dovrebbe evidentemente porre una domanda del tipo «How ought we to decide among the claims of rival and incompatible accounts of justice competing for our

\footnotetext{
${ }^{45}$ A. MacIntyre, Is a Science of Comparative Politics Possible?, in Id., Against the Self-Images of the Age, p. 260.

${ }^{46} \mathrm{Cf}$. A. Maclntyre, Whose Justice? Which Rationality?, pp. ix-x. 
moral, social, and political allegiance? ${ }^{47}$. Sarebbe difficile cercare di rispondere senza accorgersi che questa domanda si innesta rapidamente sulla questione ulteriore di che cosa sia una condotta autenticamente e indisputabilmente razionale, e chi arrivasse a compiere questo passaggio comprenderebbe che una sensazione di disagio è la reazione più ovvia di fronte al fatto che anche rispetto a questioni così importanti non si dispone, oggi, di conclusioni condivise. Ecco perché Maclntyre sostiene che la nostra condizione di eredi della modernità ci ha lasciati in uno stato di grave disagio: ci ritroviamo privi di luoghi riconoscibilmente deputati a ospitare le discussioni che dovrebbero permetterci di arrivare a quelle conclusioni, cioè privi di «institutionalized forums within which these fundamental disagreements [about justice and practical rationality] can be systematically explored and charted ${ }^{48}$. Per coloro che non si tirano indietro davanti al bisogno di mettere a confronto concezioni contrapposte sulla giustizia e sulla razionalità pratica, anche le università possono facilmente moltiplicare le occasioni di delusione, perché almeno dalla fine del Settecento si sono strutturate in modo da riprodurre al loro interno la stessa cacofonia di voci portata dalla modernità e immediatamente riscontrabile anche altrove, al livello delle credenze che ispirano le diverse pratiche. Maclntyre ne ricava perciò che:

The only [...] type of resource generally available in our society [...] is that which is supplied by participation in the life of one of those groups whose thought and action are informed by some distinctive profession of settled conviction with regard to justice and to practical rationality. Those who resorted or resort to academic philosophy hoped or hope to acquire thereby a set of sound arguments by means of which they could assure themselves and others of the rational justification of their views. Those who resort instead to a set of beliefs embodied in the life of a group put their trust in persons rather than in arguments. In doing so they cannot escape the

\footnotetext{
${ }^{47}$ Ivi, p. 2.

$48 \mathrm{Ibid}$. Anche in Dependent Rational Animals Maclntyre afferma la necessità che una società che voglia promuovere la vita buona si doti di «institutionalized forms of deliberation» (A. Maclntyre, Dependent Rational Animals, p. 129). In questo caso, però, all'interno dell'operazione di generale reindirizzo cui vengono sottoposte molte delle tesi avanzate nei lavori precedenti, queste occasioni di deliberazione non avrebbero soltanto lo scopo di realizzare la giustizia, ma anche quello di incarnare il più possibile tutte le relazioni di dare e ricevere (giving and receiving) che siano in grado di accordarsi con l'esercizio della virtù della «just generosity» (Ibid.).
} 
charge of a certain arbitrariness in their commitments, a charge, however, which tends to carry little weight with those against whom it is directed ${ }^{49}$.

Pur non avendo i medesimi difetti dell'infruttuoso confronto che si può ottenere nel mondo accademico, ciò che si ricava dall'adesione a un gruppo, ai ruoli che esso impone, alla sua determinata visione del mondo e, in qualche caso, alla sua etica rischia quindi di rivelarsi solamente come la prova della presenza di una disposizione gregaria a seguire i dettami di un capo, dettami direttamente derivanti, magari, dalle sue predilezioni personali o da sue altrettanto personali idiosincrasie. Si tratterebbe in breve di un'adesione non dettata da motivazioni razionali, perché potrebbe durare soltanto fino a quando fosse alimentata dalla continua frequentazione degli appartenenti a quello stesso gruppo. Se un confronto che sia davvero razionale deve però poter produrre risultati capaci di resistere anche al di fuori di legami di gruppo tanto stretti - e spesso tanto acritici -, diventa chiaro come neppure questa sia una soluzione soddisfacente ${ }^{50}$.

Meglio allora occuparsi direttamente, secondo Maclntyre, delle tradizioni filosofiche che nel nostro tempo si trovano a competere le une con le altre, perché sarà affrontando la questione di come privilegiarne una a scapito delle restanti che sarà forse anche possibile uscire dalla semplice e per lo più inutile giustapposizione di una posizione a un'altra che rispetto ad essa si dimostra comunque incompatibile. Si tratta quindi di considerare almeno quali dovrebbero essere i termini su cui impostare quella competizione che nessuna istituzione moderna sembra capace di ospitare davvero.

\footnotetext{
${ }^{49}$ A. Maclntyre, Whose Justice? Which Rationality?, pp. 4-5.

${ }^{50} \mathrm{Si}$ badi che qui si parla soltanto di un allentamento di legami sociali che tendono a farsi esclusivi e a circondare per intero chi ci si adegua. Maclntyre non pensa affatto che una convinzione possa dirsi razionale solo se può resistere a una completa rescissione degli ordinari legami familiari, comunitari o sociali da parte dei singoli. Al contrario, per capire come soprattutto l'ultimo Maclntyre arrivi a negare che a un individuo, fosse pure in età adulta, possa essere attribuita un'effettiva razionalità pratica se lo si considera svincolato per intero, quindi perfettamente indipendente, dalle relazioni con altri membri della sua stessa comunità, specialmente se si parla di una comunità "of giving and receiving", e dagli impegni di reciprocità maturati crescendo al suo interno, si veda A. Maclntyre, Dependent Rational Animals.
} 


\section{Le tradizioni, i modi della loro competizione e la superiorità del tomismo}

Nel confronto agonistico che mette le diverse tradizioni l'una contro l'altra, ognuna di esse non vale come un corpo tanto coeso e solidale da dimostrarsi insensibile a influssi esterni. Al contrario, ogni tradizione è internamente percorsa da linee di frattura che possono, in determinate circostanze, provocare in essa ampi spostamenti relativi, che possono essere portatori di rinnovamenti profondi come di definitivi tracolli. Entrando nello specifico dei modi in cui le tradizioni affrontano queste fasi di mutamento, si potrà osservare che, nella misura in cui sono definite da complessi di credenze che si trovano in equilibrio, esse possono subire riassestamenti tanto più estesi quanto più i rapporti interni stabilitisi fra le loro parti componenti sono a loro volta suscettibili di alterazioni. A questo proposito Maclntyre nota che:

It will have some contingent historical starting point in some situation in which some set of established beliefs and belief-presupposing practices, perhaps relatively recently established, perhaps of long standing, were put in question, sometimes by being challenged from some alternative point of view, sometimes because of an incoherence identified in the beliefs, sometimes because of a discovered resourcelessness in the face of some theoretical or practical problem, sometimes by some combination of these. So the beliefs will be further articulated, amended, modified, and added to in order that, in a newer, revised form, they may provide some answer to the questions thus raised and in that form transcend the limitations of their earlier version ${ }^{51}$.

Considerando che per i modi in cui si compie e per i suoi risultati questo sforzo di revisione può arrivare a investire una tradizione nella sua interezza oppure riguardare soltanto alcune sue porzioni, a questo discorso va anche aggiunto che il mutamento non può limitarsi a toccare solamente il livello delle credenze, ma deve estendersi in forme analoghe al livello delle pratiche che su quelle stesse credenze sono fiorite e che aderiscono alla medesima tradizione, esprimendone e insieme tendendo a fissarne il versante più schiettamente comportamentale. Detto questo, ciò

${ }^{51}$ A. Maclntyre, Three Rival Versions of Moral Enquiry, p. 116. Cf. anche Id., Whose Justice? Which Rationality?, pp. 354-358. 
su cui ora importa di più fermarsi è il fatto per cui il comunicarsi del cambiamento da un livello all'altro non obbedisce a criteri casuali, ma si gioca su un confronto fra giustificazioni razionali che comprensibilmente esibisce aspetti sia logici sia diacronici. Infatti, perché una tradizione di qualunque tipo possa rimanere identificabile anche al termine delle fasi di alterazione che l'hanno interessata e nonostante i mutamenti subiti, deve saper mostrare che una continuità lega la sua situazione passata a quella attuale, per quanto queste differiscano l'una dall'altra. Se così non fosse, non sarebbe possibile parlare di un'unica, determinata tradizione che è andata incontro a precisi mutamenti, ma occorrerebbe riferirsi piuttosto a due tradizioni distinte, dove una delle due, vale a dire quella attualmente vivente, si sarebbe imposta, sostituendola, su una tradizione precedente e ormai estinta. In breve, dal momento in cui una tradizione inizia a mostrare un difetto di risposta di fronte a problemi nuovi o a nuove istanze, essa

\begin{abstract}
will move through stages, at each of which a justification of the scheme of belief as a whole could be supplied in terms of its rational superiority to the formulations of its predecessor, and that predecessor in turn justified by a further reference backward. But the availability of this type of reference from the present to the past is not by itself sufficient to constitute a tradition of rational enquiry. It is necessary also that a certain continuity of directedness emerge, so that theoretical and practical goals to guide enquiry are formulated and at later stages reformulated ${ }^{52}$.
\end{abstract}

Essendo chiaro come secondo Maclntyre una tradizione può conoscere uno sviluppo interno, si può ora esaminare il modo in cui è in grado di dimostrarsi superiore a un'altra.

Maclntyre scrive che, innanzitutto, "For one view to have emerged from its encounter with another with its claim to superiority vindicated it must first have rendered itself maximally vulnerable to the strongest arguments which that other and

\footnotetext{
${ }^{52}$ A. Maclntyre, Three Rival Versions of Moral Enquiry, p. 116. Cf. inoltre Id., Whose Justice? Which
} Rationality?, pp. 349-355. 
rival view can bring to bear against it ${ }^{53}$. Per una concezione impegnata in un confronto, questa non è soltanto la maniera per accettarlo senza riserve e il più ampiamente possibile, ma, nel caso in cui sappia per un verso resistere ai migliori argomenti avversari e per l'altro superarne le migliori difese, anche la via per dimostrare la propria eccellenza. Le concezioni che sono particolarmente forti, nel senso che sanno ripetutamente offrire argomenti convincenti non soltanto secondo i propri criteri di razionalità, ma anche secondo quelli di concezioni rivali, godono inoltre della capacità di sopravvivere ad aggiustamenti periodici e di oltrepassare in questo modo il tempo in cui sono nate e si sono inizialmente consolidate, per arrivare in buona misura intatte anche in epoche storiche successive. In generale si può anche precisare che esse, quanto alla capacità di offrire risposte razionali ai vari problemi che si presentano di volta in volta nel passaggio da una situazione storicamente data a un'altra, risultano più inclusive, ed è questo che deve far dire che la forma di razionalità che le caratterizza è risultata essa stessa, in modi che sono emersi nel confronto, più estesa e più comprensiva di altre ${ }^{54}$.

C'è però un altro fatto notevole e che va tenuto presente, facilmente spiegabile grazie alla natura complessa di tutte le tradizioni e derivante dalla circostanza per cui non sempre queste procedono con regolarità verso un definitivo declino o verso un'incontrastata egemonia. Avviene spesso, anzi, che determinati aspetti di tradizioni particolari - aspetti che per queste tradizioni sono più o meno essenziali, a seconda dei casi - siano sottoposti a revisioni, con esiti a volte favorevoli, a volte fallimentari. Può allora anche succedere che la rivisitazione di una tradizione del passato porti a una sua riformulazione tanto brillante da conferirle una vitalità che era data per perduta. Questo è esattamente ciò che sarebbe capitato, per Maclntyre, alla tradizione aristotelica dopo la sua ripresa da parte di Tommaso, tanto che la

53 A. Maclntyre, Three Rival Versions of Moral Enquiry, p. 181. Una chiara ricostruzione di come si configuri un confronto fra tradizioni rivali e di come questo confronto sia sostanzialmente suddivisibile in stadi si trova proposta anche in Whose Justice? Which Rationality?, pp. 166-167, dove il numero di questi stadi è limitato a due.

${ }^{54}$ Cf. A. Maclntyre, Whose Justice? Which Rationality?, p. 388. 


rivendicazione alla ricerca di stampo aristotelico-tomista di un metodo
riconoscibilmente superiore rispetto ad approcci rivali può essere fatta iniziare dalla constatazione che "the Aristotelian account of justice and of practical rationality emerges from conflicts of the ancient polis, but is then developed by Aquinas in a way which escapes the limitations of the polis» ${ }^{55}$. Le vicende che hanno riguardato la tradizione tomista sono poi così esemplari da poter riassumere tutti i motivi illustrati fin qui:

\begin{abstract}
Just as a later stage within [the Aristotelian-Thomistic] tradition is held superior to an earlier stage only if and insofar as it is able to transcend the limitations and failures of that earlier stage, limitations and failures by the standards of rationality of that earlier stage itself, so the rational superiority of that tradition to rival traditions is held to reside in its capacity not only for identifying and characterizing the limitations and failures of that rival tradition as judged by that rival tradition's own standards, limitations and failures which that rival tradition itself lacks the resources to explain or understand, but also for explaining and understanding those limitations and failures in some tolerably precise way ${ }^{56}$.
\end{abstract}

Inoltre, come Maclntyre spiega a più riprese, non si può immaginare che una tradizione che voglia dimostrarsi all'altezza dei tempi possa sfuggire a un confronto critico continuo con le opere - si tratta tipicamente di testi scritti - che ne formano l'ossatura teorica fondamentale e con i metodi di insegnamento che dovrebbero assicurarne il passaggio attraverso le generazioni. Proprio la condizione attuale dell'istituzione universitaria può nuovamente servire a un'efficace rappresentazione della questione: in quello che Maclntyre ritiene essere il suo grave scadimento quale luogo di autentico confronto razionale, il contributo aristotelico-tomista potrebbe invertire la tendenza attuale alla progressiva perdita di un comune terreno di discussione. Questo fatto si produrrebbe grazie alla riproposizione di un modello di studio universitario che era vigente nella Parigi del XIII secolo e per il quale gli studenti venivano educati a concordare o a dissentire fra loro a partire dalla discussione di una

55 Ivi, p. 10.

${ }^{56}$ A. Maclntyre, Three Rival Versions of Moral Enquiry, pp. 180-181. 
tesi proposta dal maestro e sulla base di un esame critico della posiziona avversaria teso a mostrarne le debolezze interne a partire dai suoi stessi presupposti. Maclntyre ritiene che in questo modo lo scontro fra posizioni non era destinato a reiterarsi senza costrutto, ma terminava con l'imporsi di una prospettiva sistematica su altre prospettive che si erano a loro volta proposte come altrettanto sistematiche. I dissensi erano allora coltivati e ricercati non come buoni in sé, ma come testimoni del fatto che, di due o più concezioni distinte e concorrenti, una si poteva imporre sulle rivali grazie alla sua effettiva superiorità razionale ${ }^{57}$.

[...] the Thomistic contribution to the re-creation of the university as a place of constrained disagreement would involve much more of a reestablishment of thirteenth-century forms, even if with twentieth-century content. For to reembody this particular tradition it is necessary not only to reread the texts which constitute that tradition, but to do so in a way that ensures that the reader is put to the question by the texts as much as the texts by the reader. In coming to understand him or herself in the light afforded by those texts the reader also comes to understand the different kinds of authority possessed by different types of text ${ }^{58}$.

Maclntyre avverte evidentemente con forza il fascino di modelli educativi ideati per disporre tutti gli aspetti della vita di coloro che vi aderiscono nel ruolo di allievi o di apprendisti all'interno di un corpo coerente sia di nozioni sia di comportamenti, un corpo sicuramente teso a generare, insieme a un'autentica crescita personale, un'etica diffusa e condivisa. Anche quando si riferisce alla teoria delle virtù di Aristotele, si può vedere come ciò che lo attira sia un modello generale di educazione organica, giudicato come la via maestra per l'ottenimento di una crescita umana che interessa certamente i singoli, ma che non può mai non riguardare immediatamente anche le comunità:

\footnotetext{
${ }^{57}$ Cf. A. Maclntyre, Whose Justice? Which Rationality?, p. 399.

${ }^{58}$ A. Maclntyre, Three Rival Versions of Moral Enquiry, p. 233. Poco prima Maclntyre aveva indicato come i testi vadano letti «against one another», perché solo in questa maniera si evita l'errore di chi ritiene possibile una lettura neutrale, produttiva di sapere in quanto pacificamente equidistante. Una simile neutralità non sarebbe infatti raggiungibile e anzi, all'opposto, «there is no way of reading them in terms of the conflicts in which they participate independently of the reader's participation in these same conflicts or at least in the analogous conflicts of the present». Cf. Ivi, p. 229.
} 
The virtues are, on Aristotle's view, dispositions to act in specific ways for specific reasons. Education into the virtues involves the mastery, the disciplining, and the transformation of desires and feelings. This education enables one to exercise the virtues so that one not only values each of the virtues for its own sake, but understands the exercise of the virtues as also being for the sake of being eudaimon, of enjoying that kind of life which constitutes the good and the best life for human beings $\mathrm{s}^{59}$.

È però attraverso l'esaltazione del metodo di confronto dialettico che si mostrerebbe davvero quella vitalità del modello aristotelico di indagine razionale e di costruzione di posizioni condivise che per mezzo della sua ripresa in chiave tomista ha saputo superare i secoli:

It is of crucial importance [...] not only that what Aristotle presents us with are accounts of sciences which are still in the process of construction, the ideal deductive and explanatory hierarchy furnishing a conception of the telos toward which scientific enquiry moves, but also that the dialectical procedures by means of which those tasks of construction are carried out never present us with a conclusion which is not open to further revision, elaboration, emendation, or refutation. Dialectic is essentially unfinished at any point in its development ${ }^{60}$.

È proprio il fatto che la possibilità «of further dialectical development always remains open ${ }^{61}$ ciò che "renders possible the work of a tradition elaborating upon, revising, emending, and even rejecting parts of Aristotle's own work, while still remaining fundamentally Aristotelian ${ }^{62}$. Estese oltre il piano strettamente metodologico e utilizzate per produrre le regole della vita associata, le procedure dialettico-costruttive non possono che costringere le strutture politiche a «make it possible both for those whose exercise of reasoning is limited or nonexistent to have a voice in communal deliberation about what [the] norms of justice require ${ }^{63}$, anche

\footnotetext{
${ }^{59}$ A. Maclntyre, Whose Justice? Which Rationality?, p. 109. Si confronti tutto ciò con quanto di trova detto a proposito dell'educazione concepita da Tommaso in Ivi, pp. 177-180 e p. 194.

${ }^{60}$ Ivi, p. 100.

${ }^{61}$ Ivi, p. 101.

62 Ibid.

${ }^{63}$ A. Maclntyre, Dependent Rational Animals, p. 130.
} 
perché, «absent the virtues of just generosity and of shared deliberation, local communities are always open to corruption by narrowness, by complacency, by prejudice against outsiders and by a whole range of other deformities, including those that arise from the cult of local community ${ }^{64}$.

Lo stesso Maclntyre non può nascondersi, però, che i suoi inviti a ritrovare la fecondità della tradizione tomista e del modello di insegnamento universitario a essa corrispondente saranno facilmente accolti da un grande scetticismo e ne attribuisce la causa alla quasi assoluta mancanza di familiarità che i lettori contemporanei, eredi della secolarizzazione moderna, hanno con la nozione di tradizione. È infatti con accenti non propriamente ottimistici che Maclntyre scrive che «It is [...] because the conception of tradition is so little at home in modern culture - and when it does seem to appear, it is usually in the bastardized form given to it by modern political conservatism - that they find it difficult to come to terms with Aquinas' metaphysical theology ${ }^{65}$.

\section{Conclusioni}

Al termine di questa presentazione di alcune questioni maggiori fra quelle affrontate rispettivamente da Hannah Arendt e da Alasdair Maclntyre, si può dire innanzitutto che l'invito alla riscoperta della tradizione tomista che proviene dal secondo non trova nella riflessione arendtiana né una sua anticipazione né una voce che lo contraddica completamente. Dato che non si può attribuire a Maclntyre la volontà di contrastare la modernità attraverso la cancellazione della pluralità delle posizioni o la negazione di ogni spazio al conflitto fra argomenti, non si può neppure vedere nella sua filosofia una promotrice di quella chiusura dello spazio pubblico che segnerebbe anche la fine di un mondo che, secondo Arendt, per poter essere definito umano deve essere luogo comune di azione. Quando affermava che "The end of the common world has come when it is seen only under one aspect and is permitted to

${ }^{64}$ Ivi, p. 142.

${ }^{65}$ A. Maclntyre, Whose Justice? Which Rationality?, p. 165. 
present itself in only one perspective ${ }^{66}$, Arendt non avrebbe perciò potuto riferirsi immediatamente alla proposta di Maclntyre. Va infatti tenuto fermo che secondo Arendt, per comprendere la convivenza umana alla luce della sua dimensione politica, la tradizione deve cedere il primato all'azione e perciò rinunciare a tenere sotto controllo i processi che questa è in grado di mettere in moto. Nel tratto a loro comune dell'attualità, il compiere azioni e il pronunciare discorsi si dovrebbero così vedere accordata la stessa centralità già compresa da Aristotele quando, nell'occuparsi di politica, ammetteva la presenza, proprio per l'azione e il discorso, di ciò che ha in sé il suo stesso telos. Una centralità dunque tanto difficile da contestare che si può affermare come "In other words, the means to achieve the end would already be the end; and this "end", conversely, cannot be considered a means in some other respect, because there is nothing higher to attain than this actuality itself ${ }^{67}$. In un'epoca segnata dal tramonto della sfera pubblica, la capacità di agire andrebbe allora ridestata spendendosi a difesa di una nuova affermazione della dignità del pensiero e della sua rilevanza per una vita che possa essere considerata all'altezza dell'umano, soprattutto dopo che la modernità ci ha consegnato a una condizione di alienazione dalla terra mai provata né durante l'antichità né al tempo in cui la filosofia si trovava indiscutibilmente collocata nella posizione di ancilla theologiæ.

Ecco dunque perché, sebbene si possa ammettere che «[a] withdrawal from the world need not harm an individual; he may even cultivate great talents to the point of genius and so by a detour be useful to the world again ${ }^{68}$, Arendt ricorda che "with each of such retreat an almost demonstrable loss to the world takes place; what is lost is the specific and usually irreplaceable in-between which should have formed between this individual and his fellow men» ${ }^{69}$, oppure come "Without being talked about by men and without housing them, the world would not be a human artifice but

\footnotetext{
${ }^{66}$ H. Arendt, The Human Condition, p. 58.

${ }^{67}$ Ivi, p. 207.

68 H. Arendt, Men in Dark Times, p. 4.

${ }^{69}$ Ivi, pp. 4-5.
} 
a heap of unrelated things to which each isolated individual was at liberty to add one more object» ${ }^{70}$.

Ciò che invece si trova ai primi posti nell'interesse di Maclntyre è il bisogno di opporsi al movimento di lungo periodo che ha portato la filosofia moderna, soprattutto quella morale, a una situazione che in After Virtue si trova indicata come "state of great disorder»" ${ }^{71}$, ed è per questo motivo che si augura anche che quel medesimo conflitto venga ricondotto entro l'ambito di istituzioni riconosciute e animate dalla volontà di fornire un'etica condivisa in quanto razionalmente difendibile. L'importanza assegnata all'essenziale mancanza di conclusione di un confronto dialettico di provenienza già aristotelica e lo spazio che in Dependent Rational Animals è dedicato alla necessità di preservare o anche di aumentare le occasioni utili alla produzione di deliberazioni condivise su questioni di interesse generale depongono a favore dell'interpretazione per cui il pluralismo che Maclntyre avversa è in particolare quello di stampo liberale o comunque di derivazione illuministica, mentre è più disponibile ad accettare tutte le molteplicità dei punti di vista che, nel sopportare il vaglio critico, non siano ritenute riducibili ad accordo facendo valere in esse una razionalità superiore in quanto astratta.

Si può inoltre comprendere come l'esigenza di avere istituzioni capaci di servire efficacemente alla realizzazione di un'etica condivisa rappresenti davvero uno dei temi portanti di tutta la riflessione di MacIntyre se si pensa a quanto può bene accordarsi con una delle conclusioni di Three Rival Versions of Moral Enquiry - quella in cui si rivendica un ruolo di tutto rispetto al pensiero utopico, purché impiegato in vista di un cambiamento effettivo ${ }^{72}$ - ciò che veniva lamentato già in God and the Theologians, cioè che ormai «we have neither glory nor Utopia to hope for. [...] We are dominated by a present to which the idea of a radically different future is alien. What conventional politics promises us is always a brighter version of what we have now.

\footnotetext{
${ }^{70}$ H. Arendt, The Human Condition, p. 204.

${ }^{71}$ A. Maclntyre, After Virtue, p. 2.

72 Cf. A. Maclntyre, Three Rival Versions of Moral Enquiry, p. 234.
} 
This is why political talk about ends and aims is always doomed to become rhetoric ${ }^{73}$, e che è ribadito in Whose Justice? Which Rationality?, lì dove si nota come "The facts of disagreement themselves frequently go unacknowledged, disguised by a rhetoric of consensus» ${ }^{74}$.

Contro la ripetitiva giustapposizione di visioni comunque votate all'inconciliabilità, la filosofia dovrebbe allora imporsi una virata decisa e operare perché si riesca a ritrovare per la cultura del nostro tempo una chiara e riconosciuta direzione di marcia prevalente. Questo non potrà essere ottenuto in alcun modo finché si resterà ancorati a una situazione per la quale «Modern academic philosophy turns out by and large to provide means for [an] accurate and informed definition of disagreement rather than for progress toward its resolution ${ }^{75}$, e in cui anche $\mathrm{i}$ pensatori di professione per lo più indietreggiano davanti al compito di approfondire apertamente una "substantive moral enquiry» ${ }^{76}$.

Difficile dire in quale misura Arendt avrebbe potuto aderire a considerazioni di questo tipo. Credo che si debba concordare sul fatto che avrebbe condiviso almeno quella parte della proposta di Maclntyre che invita a non trasformare la riflessione filosofica istituzionale in uno sforzo intellettuale capace solamente di dare espressione alla conflittualità attuale, soprattutto se questo sforzo deve tradursi soltanto in un ripetitivo resoconto sulla contrastata situazione presente. Mi sembra però anche chiaro che la filosofia accademica desiderata da Maclntyre non sembra tenere in alcun conto la differenza fra ragione e intelletto, quindi fra attività intesa come pensare e attività intesa come conoscere, che per Arendt va ritenuta fondamentale per capire come la riflessione filosofica possa comunque salvare alcuni margini per un discorso critico anche in un tempo come il nostro, così conteso fra un'impolitica propensione ad assestarsi su un programma di parcellizzazione estrema, portata fino al livello

\footnotetext{
73 Pubblicato una prima volta in «Encounter», 1963, oggi si trova in A. MacIntyre, Against the SelfImages of the Age, pp. 12-26 (il passo citato si trova a pp. 22-23).

${ }^{74}$ A. Maclntyre, Whose Justice? Which Rationality?, p. 2.

${ }^{75} / v i$, p. 3.

${ }^{76}$ Cf. A. Maclntyre, Three Rival Versions of Moral Enquiry, pp. 235-236.
} 
dell'irrelata singolarità dei desideri, e un'opposta inclinazione a normalizzare tutte le iniziative individuali sotto il carico schiacciante della società.

Se osservata attraverso il filtro della riflessione arendtiana, credo quindi che si possa affermare che i maggiori punti di forza della filosofia di Maclntyre non risiedano nell'aperta rivendicazione della vitalità e della validità della tradizione tomista, ma che si ritrovino piuttosto sul versante epistemologico, un livello di discorso reso apprezzabile dalla consapevolezza che «To have passed through an epistemological crisis successfully enables the adherents of a tradition of enquiry to rewrite its history in a more insightful way ${ }^{77}$ e che il tipo di razionalità richiesto per andare in cerca della verità muovendosi con coerenza all'interno di una determinata tradizione prevede che, nel caso in cui questa stessa tradizione dia prove di inadeguatezza, si arrivi per lo meno a «an acknowledgment of defeat in respect of truth ${ }^{78}$. Non sembrerà perciò fuori luogo tornare alla volontà un tempo espressa da Maclntyre di non lasciare campo libero allo scetticismo e concludere nuovamente, insieme a lui, che «The most that one can hope for is to render our disagreements more constructive ${ }^{79}$.

\section{Referenze}

A. Maclntyre, Against the Self-Images of the Age. Essays on Ideology and Philosophy, London, Duckworth, 1971.

. After Virtue. A Study in Moral Theory, University of Notre Dame Press, Notre Dame, 2007.

. Three Rival Versions of Moral Enquiry. Encyclopædia, Genealogy, and Tradition, University of Notre Dame Press, Notre Dame, 1990.

. Dependent Rational Animals. Why Human Beings Need the Virtues (Carus Publishing Company, Chicago, 1999.

\footnotetext{
${ }^{77}$ A. Maclntyre, Whose Justice? Which Rationality?, p. 363.

78 Ivi, p. 365.

${ }^{79}$ A. Maclntyre, Three Rival Versions of Moral Enquiry, p. 8. 
H. Arendt. The Human Condition, The University of Chicago Press, Chicago and London, 1998.

H. Arendt, Men in Dark Times, Harcourt Brace \& Company, New York, 1968.

K. Breen, Under Weber's Shadow: Modernity, Subjectivity and Politics in Habermas, Arendt and Maclntyre, Ashgate, Farnham, 2012. 